\title{
Akuntansi Sebagai Pilihan Milenial
}

\author{
Yovita Ariani ${ }^{1)}$ \\ mkyovita_ariani@yahoo.com \\ Devica Pratiwi ${ }^{2)}$ \\ dpratiwi@bundamulia.ac.id \\ Monica Indriana ${ }^{3)}$ \\ indrianamonica3@gmail.com \\ Monica Indriani ${ }^{4}$ \\ indrianimonica3@gmail.com \\ Universitas Bunda Mulia
}

\begin{abstract}
The desire to actualize oneself will influence lifestyle and important decisions including the majors of study in University. In relation to industrial revolution, then it makes sense if a student chooses a major related to technology but based on previous data, the accounting is still ranked in the top 3 (three). The difference between the conditions of the industrial environment with the decision of students to choose an accounting as a study program gives a question mark about what factors influence a student's decision in making decision. The unit of analysis in this study is individual students. The sample used in this study was $X$ university students, majoring in accounting. PLS-SEM approach was used as statistical data analysis with SmartPLS software.

The research showed that the dimensions of information search and cost evaluation can explain the dependent variable, which is the millennial decision in choosing an accounting major. The independent variable which is career expectations and personal characteristics have a positive relationship in the decision of millennial choosing accounting majors while the perception variable does not have a negative relationship to the students's choice
\end{abstract}

Keyword : Accounting, Perception, Career Expectation, Personal Characteristic

\begin{abstract}
Abstrak
Keinginan untuk mengaktualisasikan diri akan mempengaruhi gaya hidup dan keputusan penting termasuk jurusan studi dalam perkuliahan. Jika dihubungkan dengan revolusi industri, maka adalah masuk akal jika seorang pelajar memilih jurusan yang terkait bidang teknologi tetapi berdasarkan data sebelumnya jurusan akuntansi masih menduduki peringkat 3 (tiga) besar. Adanya perbedaan antara kondisi lingkungan industri dengan keputusan pelajar memilih program studi akuntansi inilah yang memberikan tanda tanya tentang faktor-faktor apa saja yang mempengaruhi keputusan seorang pelajar dalam memutuskan program studi yang dipilih. Unit analisa dalam penelitian ini adalah individu mahasiswa/i. Sample yang digunakan pada penelitian ini adalah mahasiswa/i Universitas X, jurusan akuntansi. Analisa data bersifat statistik dengan pendekatan PLS-SEM menggunakan perangkat lunak SmartPLS.
\end{abstract}


Penelitian menghasilkan bahwa dimensi pencarian informasi dan evaluasi biaya dapat menjelaskan variabel dependen yaitu keputusan milenial dalam memilih jurusan akuntansi. Variabel independen yaitu ekspektasi karir dan karakteristik pribadi memiliki hubungan yang positif dalam keputusan para milenial memilih jurusan akuntansi sedangkan variabel persepsi tidak memiliki hubungan negative terhadap pemilihan program studi.

\section{Kata kunci : Akuntansi, Persepsi, Ekspektasi Karir, Karakteristik Pribadi}

\section{PENDAHULUAN}

Para ahli mengelompokan kaum milenial merupakan kelompok yang lahir pada awal tahun 1980 hingga awal 2000. Sebagian besar generasi ini tumbuh dengan dikelilingi oleh teknologi yang mengikuti gaya hidup kaum milenial. Berdasarkan informasi yang didapat dari pusat data Republika kaum milenial lebih memilih pekerjaan yang sesuai dengan hasrat mereka dibandingkan dengan sekedar pekerjaan yang memiliki bayaran yang besar, dengan kata lain aktualisasi diri menjadi sangat penting. Keinginan untuk mengaktualisasikan diri akan mempengaruhi gaya hidup dan keputusan-keputusan penting yang dibuat oleh kaum milenial. Revolusi industri 4.0 tentunya mempengaruhi pilihan karir sesesorang termasuk juga dalam pengambilan keputusan seorang pelajar dalam memilih jurusan bidang studi dalam perkuliahan. Jika dihubungkan dengan revolusi industri 4.0, maka secara garis besar adalah masuk akal jika seorang pelajar memilih jurusan yang terkait teknologi. Hal ini tidak sejalan dengan data peminat dalam memilih jurusan perguruan tinggi, berdasarkan informasi jumlah peserta yang mengikuti Seleksi Bersama Masuk Perguruan Tinggi Negeri (SBMPTN) 2019 yang dikutip dari kompas.com. Jurusan akuntansi masih menduduki peringkat 3 (tiga) besar. Adanya perbedaan antara kondisi lingkungan industri dengan keputusan pelajar memilih program studi akuntansi inilah yang memberikan tanda tanya tentang faktor-faktor apa saja yang mempengaruhi keputusan seorang pelajar dalam memutuskan program studi yang dipilih.

\section{Tujuan Penelitian}

Urgensi Penelitian Pemahaman mengenai faktor-faktor yang mempengaruhi keputusan seorang pelajar dalam memilih program studi akuntansi sangat diperlukan, terutama agar dapat meningkatkan minat terhadap akuntansi. Akuntan di Indonesia sangat dibutuhkan karena berdasarkan informasi yang dikutip dari Ketua Institut Akuntan Publik Indonesia (IAPI), jumlah akuntan Indonesia masih kurang jika 
dibandingkan dengan Singapura, Malaysia dan Thailand sehingga jika tidak segera ditingkatkan, akuntan dari negara tetangga dapat bekerja di Indonesia. Dengan memahami kebutuhan dan dorongan para pelajar yang merupakan kaum milenial dalam memilih program studi terutama akuntansi maka diharapkan strategi yang tepat dapat dibentuk sehingga perkembangan dunia akuntansi dapat terus ditingkatkan dan dapat menghasilkan akuntan profesional, terutama di Indonesia. Berdasarkan hal tersebut maka penelitian ini bertujuan untuk:

a. Mengetahui apakah ada hubungan positif antara pilihan mahasiswa jurusan akuntansi dan faktor bimbingan

b. Mengetahui apakah ada hubungan positif antara pilihan mahasiswa jurusan akuntansi dan faktor ekspektasi karir

c. Mengetahui apakah ada hubungan negatif antara pilihan mahasiswa jurusan akuntansi dan faktor persepsi

d. Mengetahui apakah ada hubungan positif antara pilihan mahasiswa jurusan akuntansi dan faktor karakteristik pribadi

Dalam penelitian ini, peneliti hanya membahas mengenai faktor-faktor yang mempengaruhi keputusan mahasiswa dalam memilih program studi akuntansi di Universitas $\mathrm{X}$ dan tidak membahas mengenai strategi yang dapat dilakukan dalam meningkatkan minat terhadap akuntansi berdasarkan hasil penelitian ini.

\section{LANDASAN TEORI}

Pengembangan hipotesis mengenai penelitian mengenai faktor-faktor yang mempengaruhi milenial memilih akuntansi, menggunakan penelitian terdahulu sebagai dasar. Terdapat banyak faktor yang mempengaruhi keputusan seorang pelajar dalam memilih suatu program studi, khususnya akuntansi. Seng (2016) mengelompokan faktor-faktor yang mempengaruhi seseorang memilih program studi menjadi 4 (empat) kelompok berdasarkan penelitian yang telah dilakukan sebelumnya yang akan dijelaskan berikut

a. Guidance factor / Faktor bimbingan Dalam pengambilan keputusan mementukan program studi, para pelajar dipengaruhi oleh pengaruh orang-orang disekitar mereka seperti orang tua, keluarga, guru, dan teman. Dalam studi yang dilakukan oleh Mauldin et.al (2000) menemukan bahwa orang tua memiliki pengaruh 
terhadap pilihan pelajar. Seng (2016) menyatakan bahwa faktor bimbingan merupakan faktor yang paling mempengaruhi seorang pelajar memilih program studi.

\section{H1 : Terdapat hubungan positif antara pilihan mahasiswa jurusan akuntansi dan faktor bimbingan}

b. Career expectation factor / Ekspektasi karir Pemilihan suatu program studi tentu diharapkan memiliki jenjang karir yang cemerlang. Oleh sebab itu, keputusan memilih suatu program studi juga didasarkan pada harapan akan karir masa depan, termasuk didalamnya gaji yang tinggi, ketersediaan lapangan pekerjaan dan kesempatan untuk dipromosikan lebih cepat. Lowe dan Simons (1997), menyimpulkan bahwa kesempatan mendapatkan uang lebih besar mempengaruhi pilihan pelajar. Pelajar yang memilih akuntansi secara signifikan tergantung dari faktor keuangan dan lapangan kerja (Dalc, 2013). Hal ini berbeda dengan penelitian yang dilakukan oleh Seng (2016), yang menyatakan bahwa pilihan mengambil program studi akuntansi tidak berhubungan dengan harapan karir seorang pelajar.

H2 : Terdapat hubungan positif antara pilihan mahasiswa jurusan akuntansi dan faktor ekspektasi karir

c. Perception factor / Faktor persepsi Keputusan dalam memilih program studi akuntansi tergantung dari pandangan mereka terhadap pelajaran mengenai perkenalan terhadap akuntasi, sehingga untuk menarik minat para pelajar untuk memilih program studi akuntansi sangat penting untuk merancang program pendidikan akuntansi yang menarik. Tan dan Laswad (2006) menyatakan bahwa persepsi tentang profesi akuntansi memegang peranan penting dalam keputusan pelajar. Sugahara et.al. (2008) menjelaskan tantangan menjadi anggota akuntan professional mempengaruhi secara negatif pelajar dalam memilih. Dengan adanya perbedaan hasil penelitian terdahulu maka penelitian ini mengembangkan hipotesis sebagai berikut

\section{H3 : Terdapat hubungan negatif antara pilihan mahasiswa jurusan akuntansi dan faktor persepsi}

d. Personal characteristic factor / Faktor karakteristik pribadi Keputusan dalam memilih program studi dipengaruhi oleh ketertarikan seseorang dan kepribadian 
seseorang. Malgwi et.al. (2005) dalam penelitian terdahulu menyatakan bahwa pilihan program studi tergantung dari ketertarikan mereka terhadap bahan pelajaran.

\section{H4 : Terdapat hubungan positif antara pilihan mahasiswa jurusan akuntansi dan faktor karakteristik pribadi}

\section{Penelitian Terdahulu}

Penelitian mengenai faktor yang mempengaruhi tindakan seseorang terutama keputusan dalam memilih suatu jurusan khususnya akuntansi telah dilakukan oleh peneliti sebelumnya dengan hasil yang beragam dikarenakan kondisi lingkungan yang berbeda termasuk juga karakteristik dari populasi. Beberapa penelitian sebelumnya diantaranya adalah sebagai berikut:

- Lim Chhoung Tang Cheaseth Seng (2016) dalam Factors influence students' choice of accounting major in Cambodian universities menyatakan bahwa faktor bimbingan adalah faktor yang paling berpengaruh yang mempengaruhi pilihan siswa untuk jurusan akuntansi diikuti oleh karakteristik pribadi sebagai faktor kedua yang paling berpengaruh. Penelitian tersebut juga mengungkapkan bahwa plihan jurusan akuntansi memiliki hubungan negatif dengan faktor ekspektasi karier, dan hubungan negatif tetapi tidak signifikan dengan faktor persepsi

- Ihan Dalc, Huseyin Arasl, Mustafa Tümer Sarvnaz Baradaran (2013) dengan penelitian berjudul Factors that influence Iranian students' decision to choose accounting major menyatakan bahwa Faktor keuangan dan pasar kerja sebagai hal yang penting, semakin besar kemungkinan mereka akan mengambil jurusan akuntansi. Dalc et.al juga meyatakan bahwa pendapat referensi dalam memilih jurusan akuntansi juga berpengaruh terhadap pengambilan keputusan. Temuan ini mungkin disebabkan oleh fakta bahwa orang-orang saling berhubungan erat dan mereka sebagai kelompok harus dipertimbangkan sebelum individu

- Gene Smith (2005) dalam penelitian berjudul Reversing the decreasing trend of students majoring in accounting menyatakan bahwa Banyak mahasiswa jurusan akuntansi membuat keputusan mereka untuk mengambil jurusan akuntansi saat mengambil kursus Prinsip Akuntansi. Selain itu, penelitian tersebut menemukan bahwa mahasiswa akuntansi menyatakan mereka membuat keputusan untuk jurusan akuntansi tanpa pengaruh signifikan oleh pihak luar 


\section{Metode Penelitian}

Metode penelitian ini adalah kuantitatif yang digunakan untuk meneliti pada populasi atau sampel tertentu. Strategi penelitian yang digunakan dalam penelitian ini adalah melalui survei . Pengaruh peneliti dalam penelitian atau dengan kata lain korelasi antara peneliti dengan objek penelitian ini adalah minimal dengan menganalisa kejadian yang secara normal terjadi tanpa memanipulasi variabel penelitian. Rentang waktu penelitian ini adalah data diperoleh satu kali, pengumpulan data dalam satu waktu dianggap cukup dalam rangka menjawab pertanyaan penelitian. Unit analisa dalam penelitian ini adalah individu mahasiswa/i dalam rangka mengetahui faktor-faktor yang mempengaruhi keputusan memilih akuntansi secara individu. Sample yang digunakan pada penelitian ini adalah mahasiswa/i Universitas X tahun ajaran 2019/2020 jurusan akuntansi. Jumlah sampel yang diambil adalah 100 (seratus) atau $\mathrm{n}=100$ dengan mempertimbangkan besarnya populasi serta batasan biaya dan waktu. Pada penelitian sebelumnya menyarankan bahwa jumlah sampel sebanyak 100 (seratus) sampai dengan 200 (dua ratus) adalah cukup untuk menguji suatu model (Hoyle, 1995) seperti yang ditulis kembali Kwong (2013).

Penelitian ini menggunakan metode purposive sampling sebagai teknik pengambilan sampel karena hanya mahasiswa yang mengambil program studi akuntansi yang dipilih sebagai responden. Penelitian ini menggunakan skala yang berupa skala nominal dan skala Likert untuk mengukur seberapa kuat para responden setuju dengan pernyataan (Sekaran, 2016). Skala nominal digunakan dalam penelitian ini untuk mengelompokan kategori tertentu atau kelompok tertentu, sedangkan skala Likert digunakan untuk mengukur opini atau tindakan yang digambarkan dari skala 1 (satu) yaitu sangat tidak mempengaruhi / sangat tidak penting / sangat tidak setuju sampai dengan 4 (empat) yaitu sangat mempengaruhi / sangat penting / sangat setuju.

\section{Teknik Pengumpulan Data}

Penelitian ini menggunakan kuisioner sebagai instrumen penelitian dalam rangka mengumpulkan data, yang disebar secara random dan personal. Penggunaan kuesioner dalam penelitian ini merupakan data primer yang berasal dari para responden secara 
langsung. Daftar pertanyaan yang digunakan dalam penelitian ini, menggunakan penelitian sebelumnya yang dilakukan oleh Seng (2016) yang telah diuji dalam penelitian sebelumnya.

\section{Teknik Analisis Data}

Analisa data bersifat statistik dengan tujuan untuk menguji hipotesis yang telah diterapkan dengan pendekatan Partial Least Square-Structural Equation Modelling (PLS-SEM) menggunakan perangkat lunak SmartPLS. Langkah pertama dalam analisis adalah menentukan reliabilitas dan validitas. Reliabilitas merupakan alat untuk mengukur suatu kuesioner yang merupakan indikator dari variabel. Suatu kuesioner dikatakan reliabel atau handal jika jawaban seseorang terhadap pernyataan adalah konsisten atau stabil dari waktu ke waktu (Ghozali, 2018). Uji validitas digunakan untuk mengukur sah atau valid tidaknya suatu kuesioner. Suatu kuesioner dikatakan valid jika pertanyaan pada kuesioner mampu untuk mengungkapkan sesuatu yang akan diukur oleh kuesioner tersebut (Ghozali, 2018). Indikator yang memiliki factor loading dibawah 0,7 akan dibuang untuk kemudian dilakukan analisis kembali.

Setelah data sudah valid dan dapat diandalkan maka langkah selanjutnya adalah melakukan evaluasi atas model yang terdiri dari langkah berikut:

1. Uji model pengukuran (Outer model analysis): terdiri dari factor loading, Average Extracted Variance (AVE) dan composite reliability serta cronbach's alfa. Factor loading yang semakin mendekati 1 maka variabel dapat dianggap semakin dapat diandalkan. Garson (2016) mengemukakan beberapa nilai batas minimum (cut-off value) dari setiap kriteria yang harus dipenuhi agar sebuah model penelitian dianggap valid dan dapat diandalkan. Indikator yang memiliki loading factor kurang dari batas minimum dapat dipertimbangkan untuk dikeluarkan dari pengujian (Hair, 2014). Cronbach alpha digunakan untuk mengukur konsistensi internal konstruksi. Composite reliability merupakan alternatif pilihan selain Cronbach's alpha yang lebih dipilih oleh para ahli dalam penelitian dikarenakan alpha Cronbach mungkin melebih-lebihkan atau meremehkan reliabilitas skala (Garson, 2016). Titik batas dalam composite reliability sama dengan yang digunakan pada cronbach's alpha. AVE mencerminkan komunitas rata-rata untuk setiap faktor laten dalam model reflektif. Dalam model yang memadai, AVE harus lebih besar dari 0,5. AVE di bawah 0,50 berarti varians kesalahan melebihi varians yang dijelaskan. 
2. Uji model struktural (Inner model analysis)

Hair et al. (2011) mengemukakan bahwa uji model struktural dilakukan untuk melihat kekuatan hubungan antar variabel di dalam model tersebut. Henseler et al., (2009) selanjutnya mengemukakan bahwa terdapat beberapa kriteria yang dapat digunakan oleh seorang peneliti untuk melakukan analisis model struktural terhadap model penelitian yang sedang digunakan.

Hasil hipotesis penelitian ditolak apabila nilai t-statistics yang muncul kurang dari nilai batas minimum (cut-off value) yang telah ditentukan, yaitu sebesar 1,96 (tstatistics < 1,96). Hipotesis penelitian diterima apabila nilai t-statistics yang muncul melebihi nilai batas minimum (cut-off value) yang telah ditentukan, yaitu sebesar 1,96 $(\mathrm{t}-$ statistics $>1,96)$.

Dalam penelitian ini outer model dan inner model digambarkan pada gambar 3.1 untuk dilakukan pengujian.

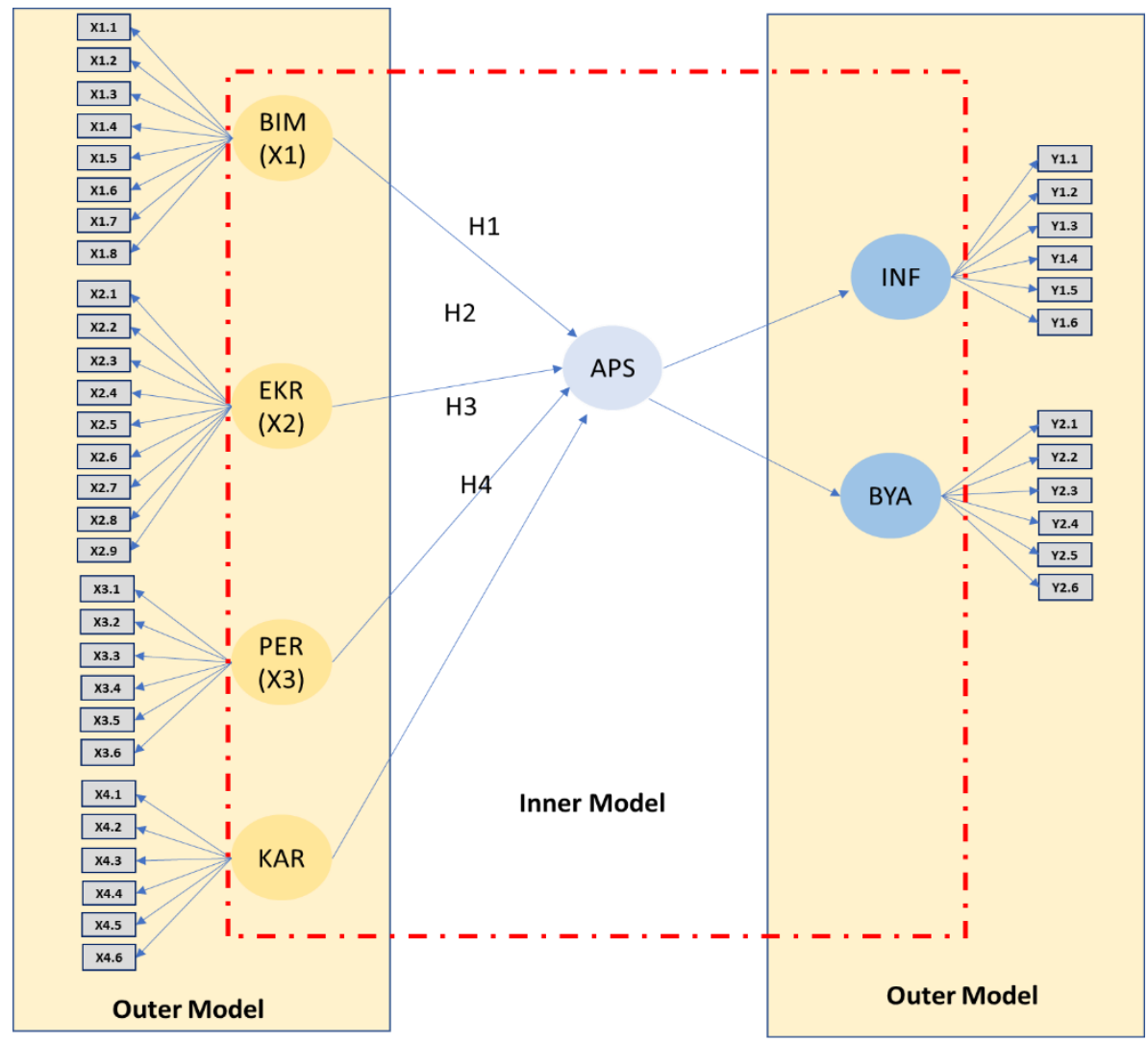

Gambar 3.1 Outer dan Inner Model Penelitian

Sumber: Diolah oleh peneliti 


\section{Hasil dan Pembahasan}

\section{Uji Model Pengukuran (Outer Model) Variabel Dependen}

Dalam uji ini, pengukuran validitas dan reliabilitas dilakukan untuk mengukur tingkat keandalam kusioner. Intrumen yang digunakan untuk menentukan validitas adalah nilai loading factor sedangkan untuk reliabilitas adalah cronbach alpha. Hasil dari uji outer model pertama menunjukan ada beberapa indikator yang mempunyai nilai loading factor kurang dari 0,7 sehingga indikator tersebut dapat dikatakan kurang valid. Indikator tersebut kemudian dikeluarkan dari analisa yaitu indikator Y1.3 (lokasi kampus) dan Y1.6 (beasiswa) dalam dimensi pencarian informasi. Setelah mengeluarkan indikator yang memiliki nilai kurang dari 0,7 , kemudian dilakukaan tes kembali. Hasil uji kedua untuk outer model dalam menguji validitas dan reliabilitas dapat dilihat pada gambar 4.1. Dari gambar tersebut semua nilai loading factor sudah diatas 0,70. Nilai AVE pada hasil uji ini dapat dilihat pada tabel 4.1 yang menujukan semua variabel memiliki nilai AVE melebihi 0,5. Hasil output tersebut menunjukan bahwa intrumen kuisioner dapat dinyatakan valid. Cronbach's alpha dan composite reliability untuk masing-masing dimensi melebihi 0,8 sehingga dapat dinyatakan bahwa instrumen kuisioner dapat digunakan untuk tujuan konfirmasi karena dapat diandalkan.

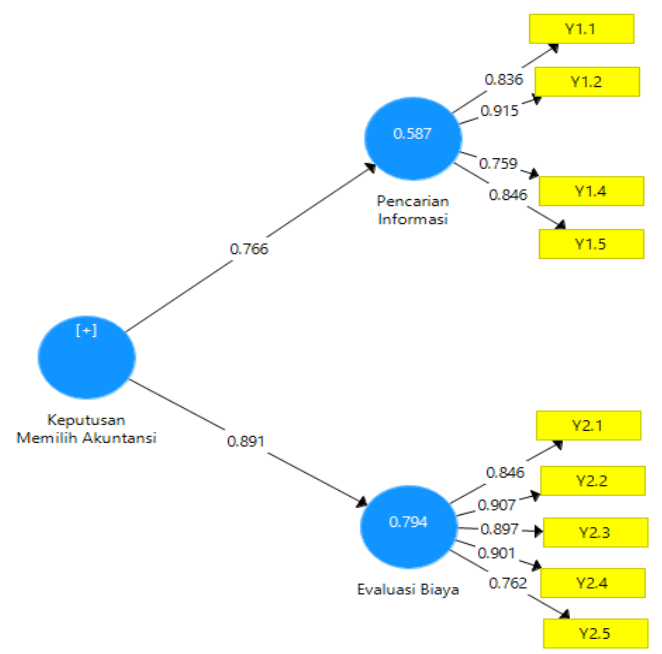

Gambar 4.1 Loading Factor Uji Kedua Outer Model Variabel Dependen Sumber: Olahan PLS

Tabel 4.1 Hasil Uji Outer Model Variabel Dependen

\begin{tabular}{|c|c|c|c|}
\hline & AVE & $\begin{array}{c}\text { Cronbach's } \\
\text { Alpha }\end{array}$ & $\begin{array}{c}\text { Composite } \\
\text { Reliability }\end{array}$ \\
\hline Pencarian informasi & 0.707 & 0.861 & 0.906 \\
\hline
\end{tabular}




\begin{tabular}{|l|l|l|l|}
\hline Evaluasi biaya & 0.747 & 0.914 & 0.936 \\
\hline
\end{tabular}

Sumber: Olahan PLS

\section{Uji Model Struktural (Inner Model) Variabel Dependen}

Analisa inner model dilakukan untuk memastikan bahwa model struktural akurat. Hasil output dari pengujian inner model dapat dilihat pada tabel 4.2. Output tersebut menunjukan bahwa $\mathrm{T}$ statistik diatas 1.96 dan $\mathrm{P}$ value dibawah 0.05 untuk kedua dimensi sehingga dapat disimpulkan bahwa variabel Y1 dan Y2 yang menjadi dimensi dapat digunakan untuk merepresentasikan variabel dependen.

Tabel 4.2 Hasil Uji Inner Model Variabel Dependen : T Statistik dan P-values

\begin{tabular}{|l|c|c|}
\hline & P-values & T statistik \\
\hline $\begin{array}{l}\text { Faktor yang mempengaruhi keputusan } \\
\text { memilih akuntansi --> Evaluasi biaya }\end{array}$ & 0,000 & 39,057 \\
\hline $\begin{array}{l}\text { Faktor yang mempengaruhi keputusan } \\
\text { memilih akuntansi --> Pencarian informasi }\end{array}$ & 0,000 & 13,040 \\
\hline
\end{tabular}

Sumber: Olahan PLS

Dari hasil output penggujian inner model $\mathrm{R}$ square memiliki nilai 0,794 untuk evaluasi biaya dan 0,588 untuk pencarian informasi. Hal ini berarti evaluasi biaya memiliki pengaruh yang kuat dalam merepresentasikan Y atau sebesar 79,4\% dan pencarian informasi memiliki pengaruh moderat dalam merepresentasikan $\mathrm{Y}$ yaitu sebesar 58,8\%. Dari hasil perhitungan R square juga dapat disimpulkan bahwa variabel Y1 dan Y2 yang menjadi dimensi dapat digunakan untuk merepresentasikan variabel dependen.

\section{Uji Model Pengukuran (Outer Model) Variabel Independen}

Hasil loading factor pada pengujian pertama menunjukan bahwa variabel X1 yaitu faktor bimbingan memiliki nilai yang lebih kecil dari 0,7 sehingga variabel ini harus dikeluarkan dari pengujian karena tidak valid sehingga tidak dapat menjelaskan Y. Indikator X2.7 (prestise sosial yang diberikan oleh karir), X3.1 (keinginan untuk menjadi anggota profesi), X3.2 (keanggotaan profesi meningkatkan gengsi), X.3.3 (tantangan dalam menjadi anggota profesi), X4.1 (ketertarikan terhadap matematika), X4.3 (mata kuliah sekarang adalah matakuliah alternatife kedua), X4.5 (kreatifitas 
bukan hal yang utama) juga memiliki loading factor kurang dari 0,7 sehingga harus dikeluarkan dari pengujian. Setelah mengeluarkan indikator yang memiliki loading factor kurang dari 0,7, kemudian dilakukan kembali perhitungan dan menghasilkan output pada gambar 4.2. Tabel 4.3. menunjukan nilai AVE melebihi 0.5 untuk ketiga variabel, sehingga instrumen kuisioner dapat dinyatakan valid. Cronbach's alpha dan composite reliability untuk masing-masing variabel melebihi 0,8 sehingga dapat dinyatakan bahwa instrument kuisioner dapat digunakan untuk tujuan konfirmasi karena dapat diandalkan.

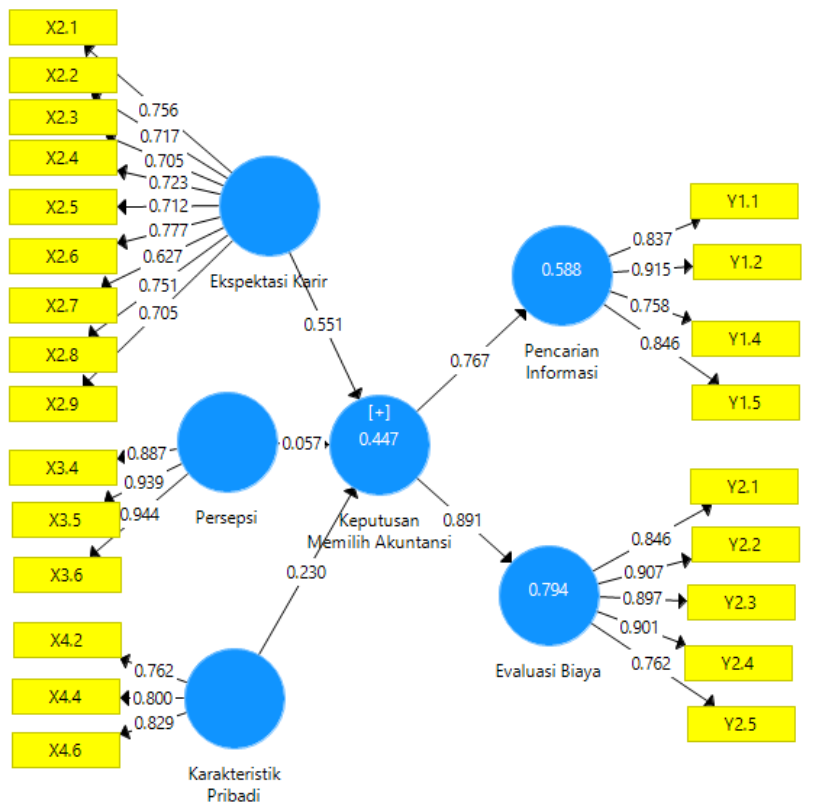

Gambar 4.2 Loading Factor Uji Kedua Outer Model Variabel Independen Sumber: Olahan PLS

Tabel 4.3 Hasil Uji Outer Model Variabel Independen

\begin{tabular}{|l|c|c|c|}
\hline & AVE & Cronbach's Alpha & $\begin{array}{c}\text { Composite } \\
\text { Reliability }\end{array}$ \\
\hline Ekspektasi karir & 0.519 & 0.884 & 0.906 \\
\hline Persepsi & 0.853 & 0.917 & 0.946 \\
\hline Karakteristik pribadi & 0.636 & 0.727 & 0.840 \\
\hline
\end{tabular}

Sumber: Olahan PLS

Uji Struktural (Inner Model) Variabel Independen 
Hasil output dari pengujian inner model dapat dilihat pada tabel 4.4. Output tersebut menunjukan bahwa $\mathrm{T}$ statistik untuk variabel ekspektasi karir dan karakteristik pribadi adalah diatas 1,96 dan $\mathrm{P}$ value dibawah 0,05. Variabel persepsi memiliki $\mathrm{T}$ statistik kurang dari 1,96 dan $\mathrm{P}$ value melebihi 0,05. Hal tersebut menunjukan bahwa hanya faktor ekspektasi karir dan karakteristik pribadi yang dapat menjelaskan variabel dependen $\mathrm{Y}$ yaitu mengenai keputusan mahasiswa dalam memilih jurusan.

Tabel 4.4 Hasil Uji Inner Model Variabel Independen: T Statistik dan P-values

Sumber: Olahan PLS

\begin{tabular}{|l|c|c|}
\hline & P-values & T statistik \\
\hline Ekspektasi karir & 0,000 & 6,196 \\
\hline Persepsi & 0,467 & 0,727 \\
\hline Karakteristik pribadi & 0,005 & 2,830 \\
\hline
\end{tabular}

Perhitungan R square sebesar 0,447 yang berarti secara keseluruhan variabel independen memiliki pengaruh sebesar $44,7 \%$ dalam pengambilan keputusan milenial dalam memilih akuntansi, sedangkan 55,3\% dipengaruhi faktor lain selain faktor bimbingan, faktor ekspektasi karir, faktor persepsi dan faktor karakteristik pribadi.

\section{Pembahasan Hipotesis}

Penelitian ini menggunakan dimensi untuk menggambarkan variabel dependen $\mathrm{Y}$ yaitu faktor pencarian informasi (Y1) dan evaluasi biaya (Y2). Indikator yang berupa lokasi kampus dan beasiswa pada Y1 memiliki loading factor $<0,7$ sehingga dikeluarkan dari pengujian. Hal ini menggambarkan bahwa kedua hal tersebut tidak dapat menjelaskan pencarian informasi pada kaum milenial. Sebaliknya akreditasi, fasilitas, prestasi maupun kurikulum suatu program studi memiliki loading factor $>0,7$ dan dapat menjelaskan pencarian informasi. Tampak dari hasil output bahwa semua indikator mengenai pertimbangan biaya memiliki loading factor $>0,7$. Perhitungan mengenai biaya hidup, transportasi, uang kuliah dan biaya perlengkapan yang dibutuhkan suatu program studi memiliki pengaruh besar sehingga indikator-indikator tersebut dapat menjelaskan Y2.

Penelitian ini pada awalnya memiliki 4 (empat variabel independen) yang terdiri dari faktor bimbingan (X1), faktor ekspektasi karir (X2), faktor persepsi (X3) dan faktor karakteristik pribadi (X4). Meskipun demikian, berdasarkan nilai loading factor 
$\mathrm{X} 1$ harus dikeluarkan dalam penelitian karena memiliki loading factor $<0,7$ sehingga tidak dapat menjelaskan variabel Y. Oleh sebab itu pertanyaan hipotesis mengenai H1 adalah tidak valid. Hasil output menunjukan bahwa pengaruh masyarakat, dorongan dari pemerintah maupun asosiasi akuntan bahkan memiliki loading factor negative terhadap variabel X1. Hal ini dapat menunjukan bahwa para kaum milenial tidak terpengaruh oleh lingkungan mereka dalam membuat keputusan, hasil ini berbanding terbalik jika dikaitkan dengan penelitian sebelumnya yaitu faktor bimbingan memegang peranan yang sangat besar.

Faktor ekspektasi karir (X2) memiliki nilai P-value $<0,05$ dan T statistik > 1,96 sehingga hipotesis untuk X2 diterima yaitu bahwa terdapat hubungan yang positif antara pilihan mahasiswa jurusan akuntansi dan faktor ekspektasi karir. Indikator mengenai karir yang dapat diberikan oleh jurusan akuntansi akan memberikan prestise sosial yang lebih tinggi tampaknya tidak menjelaskan variabel X2 dengan loading factor $<0,7$ sehingga dikeluarkan dari pengujian. Harapan akan memiliki penghasilan yang tinggi mempengaruhi keputusan para milenial dalam memilih jurusan termasuk juga ketersediaan lapangan kerja yang membutuhkan jurusan akuntansi. Selain itu, fleksitabilitas dan pilihan karir yang lebih banyak jika mengambil jurusan akuntansi juga menggambarkan variabel $\mathrm{X} 2$.

Nilai P-value 0,4677 >0,05 dan T statistic 0,828 < 1,96 untuk hipotesis H3 sehingga hipotesis ditolak yaitu tidak ada hubungan negatif antara pilihan mahasiswa jurusan akuntansi dan faktor persepsi. Berdasarkan nilai loading factor, tampak bahwa pengaruh profesi akuntan memiliki loading factor $<0,7$ sehingga dikeluarkan dalam pengujian. Profesi akuntan tampaknya tidak menjelaskan variabel X3, keinginan para milenial untuk menjadi anggota profesi sangat minim. Jurusan maupun nilai yang diperoleh di bangku sekolah memiliki loading factor $>0,7$ sehingga dapat menjelaskan variabel X3 dengan nilai yang didapatkan disekolah mempengaruhi keputusan dalam memilih jurusan dengan nilai 0,901

Karakteristik pribadi memiliki P-value 0,005 < 0,05 dan T statistik 2,830 > 1,96 sehingga $\mathrm{H} 4$ diterima yaitu bahwa terdapat hubungan yang positif antara pilihan mahasiswa jurusan akuntansi dan faktor karateristik pribadi. Ketertarikan terhadap matematika dan kreativitas memiliki loading factor $<0,7$ demikian juga mengenai akuntansi sebagai pilihan alternatif terbaik sehingga indikator tersebut dikeluarkan dari pengujian karena tidak menggambarkan karakteristik pribadi. Ketertarikan dengan angka maupun sistem keuangan memiliki nilai > 0,7 termasuk juga minat 
milenial dalam memilih jurusan. Ketiga hal ini sebagai indikator mewakili X4 sebagai variabel karakteristik pribadi.

\section{DAFTAR PUSTAKA}

Dalc, lhan, Huseyin Arasl, Mustafa Tümer Sarvnaz Baradaran. (2013). Factors that influence Iranian Students' Decision to Choose Accounting Major. Journal of Accounting in Emerging Economies, Vol. 3 Iss 2 pp. 145 - 163.

Hair, Joseph F; Hult, G. Tomas; Ringgle, Christian M; Sarstedt, Marco (2014). A Primer on Partial Least Squares Structural Equation Modeling (PLS-SEM). SAGE publication Inc.

Hoyle, R.H. (ed.) (1995). Structural Equation Model. Thousand Oaks, CA.:SAGE Publication, Inc.

Kwong, Ken; Wong, Kay (2013). Partial Least Square Structural Equation Modeling PLS-SEM Techniques Using SmartPLS. Marketing Buletin, 24, Technical Note 1

Lowe, D., \& Simons, K. (1997). Factors influencing choice of business majors--some additional evidence: a research note. Accounting Education: an international journal , $6(1), 39-45$

Malgwi, C., Howe, M., \& Burnaby, P. (2005, June ). Influence on students' choice of college major. Journal of Education for Business , 275-279

Mauldin, s., Crain, J., \& Mounce , P. (2000). The accounting principles instructor's influence on student's decision to major in accounting . Journal of Education for Business , 142-148

Sekaran, Uma; Bougie, Roger (2016). Research Method for Business 7th ed. John Wiley and sons, UK.

Seng, Cheaseth, Lim Chhoung Tang. (2016). Factors influence students' choice of accounting major in Cambodian universities. Asian Review of Accounting, Vol. 24 Iss 2

Smith, Gene. (2005). Reversing the decreasing trend of students majoring in accounting. Managerial Auditing Journal, Vol. 20 Iss 9 pp. 936 - 944 
Sugahara, S., Boland, G., \& Cilloni, A. (2008). Factors influencing students' choice of an accounting major in Australia. Accounting Education: an international journal 17, S37-S54. 